\title{
AN ANALYSIS OF CODE SWITCHING USED IN CLASSROOM
}

\author{
Friskila N. Gerungan, Sanerita T. Olii, Fivy Andries
}

\begin{abstract}
This study is aimed at analysing the forms or types of code switching and describing the meaning of the forms used by teacher or students in English learning process in classroom. In conducting this reseearch, the writer used descriptive method. The data were taken during English lerning process, where, there are teacher and students in. To collect the data the writer used recorder and notes. The data collected were analyzed by doing Unitization, Categorization, Explanation and Interpretation in English words and sentence, used as code switching during the classroom.

The findings in this study show that code switching used by teacher and students during the English learning process are form of intersentensial code switching, intrasentensial code switching and tag switching. The meaning of those forms or sentence depend on structure of the sentence or context of the sentence. It is expected that, this research can give a contribution to the development of sosiolinguistics, and give motivation to other researcher to combine or improve the same topic of research in the future to develop English leraning process.
\end{abstract}

Keywords: Code Switching, English Learning Process

\section{INTRODUCTION}

Indonesia is a unique country. Why? Not only many people but also most of the people in Indonesia are able to speak in two languages: what are the languages? The first is the mother tongue, second is national language. This happens because Indonesia has many diverse cultural and linguistic variations.

Indonesia could also be regarded as a multilingual country; especially in big cities are often in contact with foreign cultures. Most of the population is not only able to speak their mother tongue and the national language, but is also able to speak the foreign language.

Richards (2000:72) states that: "code switching is a change by a speaker or writer from one language or language variety to another one. Code switching can take place in a conversation when one speaker uses 
one language and the other speaker answers in different language. A person may start speaking one language and then change to another one in the middle of their speech, or sometimes even in middle of sentences."

In modern era, English as an international language has an important role to develop science and technology. "Language is fundamental to all social processes, and human do need language to communicate to each other. In social process, there are people, who communicate more than they say, they use language that indicate meanings more than the language does." (Maru et al, 2016: 1) Many People who have knowledge and skill in a current language always try to switch or mix codes in their speech fluently. In English activity in classroom, Based on the curriculum, the students should be familiar with the four language skills such as listening, speaking, reading and writing. In studying English, all of the students should be able to use the four languages skill that is why they are important to learn and to practice for increasing their skills. For this, the students must have linguistic competence such as grammar or structure and vocabulary and to use them in spoken language.

In this study, the writer would like to know the code switching in teaching and learning process. The phenomenon of code switching widely occurs within the communication in which more than one language is used. Also it is noticeable for them to speak mixed languages and they also switch back and forth between two languages. In order to understand the process of their utterances, it is necessary to study code switching in the area of bilingualism.

Sometimes, English makes students confused or bored to studying, because they will get difficult in comprehending the materials. To solve the problem, most of the English teacher in Indonesia use more than one language. Teacher and students mixing up in the communication of teaching and learning process in the language classes. "Students and teachers were two important figures in the teaching and

JELLT (Journal of English Language and Literature Teaching)

Vol. 5 No.01 June 2020

P.ISSN: 2548-7728 E.ISSN: 2599-0373 
learning process. In the situation such as Indonesia, less student-centered but more teacher-centered was the common approach applied in the classroom all across subject areas." (Liando, 2010:2) In this study we can find out that code-switching used by teacher and student in classroom.

In formal education, codeswitching are needed for English Teacher in teaching process because it makes students easier and interested on understanding the lesson. "In relation to attitudes and learning, student motivation was found to be one variable associated with being successful in language learning." (Liando, 2010: 4)

In addition, it would be better for the teacher to try to teach students with code-switching so that the students could be familiar with bilingual condition. Concerning the background of the study of this research, the writer formulated the problem of the study was what types of Code Switching used by teachers and students in English learning activity in classroom?
- In order to get focus in conducting this study, the study was delimited to: The code Switching used by teacher and students in English learning process of The Second Year Students SMA Negeri 1 Kakas.

In English teaching and learning process, the writer wanted to helping teachers to know the types dan reason of code Switching used by teacher and students in speaking skill and as a contribution to English teacher in overcoming students problem in studying English in classroom.

\section{RESEARCH METHODOLOGY}

\section{Research Design}

To analyze this research, writer used a descriptive method. Best (1978:116) stated that:

"a descriptive study describes and interprets what is. It is concerned with conditions or relationship that exist, opinions that are held, process 
that are going on, effect that are evidences, or trends that are developing. It is primarily concerned with the present, although it often considers past evidences and influence as they relate to current conditions."

Bogdan and Biklen (1992:28) point another relation opinion: "Qualitative research is descriptive. The data collected are in the form of words of or a picture rather than number. The written results of the research contain quotation from the data to illustrate and substantinate the presentation."

\section{Source of the Data}

The sources of the data took from The Second Year Students of SMA Negeri 1 Kakas.

\section{Research Procedures}

In doing the research, the steps used are:

- The writer came to school and met the head master and ask for permission to make a research in that school.

- The writer collected the data by recording the conversation in Speaking Class to get the natural data

- After collected the data, writer observed the script by watching it directly

- While observed the data, writer took a note whenever founding a code switching

- After all data founded, writer analyzed the data from the recorded and written data.

- The last was classifies the form code switching made by students

\section{Research Instrument}

To collect the data, the writer used recorder and notes.

\section{Data Analysis}

The collected data analyzed according to steps of qualitative research. The steps used in analyzing the data followed the steps of qualitative data by Bogdan and Biklen (1992: 145), are:

- The activity of unitization

JELLT (Journal of English Language and Literature Teaching)

Vol. 5 No.01 June 2020

P.ISSN: 2548-7728 E.ISSN: 2599-0373 
In this step, all the data united according to the notes and record. In the process of unitization, the coding is done to make the controlling easily done.

- The activity of categorization In this step, the data categorized according to the criteria of type of code switching namely: inter sentential code-switching, intra sentential code-switching, and tagswitching.

- The activity of explanation In this step, the categorized of the data explained according to findings in the first and second steps. In explaining the data united and categorized, comparison used to help the writer in making interpretation and drawing conclusion.

- The activity of interpretation

The last step was the activity of making interpretation. The data that have been united, categorized, and explained interpreted or concluded as the findings of the study.

\section{RESEARCH FINDINGS AND DISCUSSION}

Unitization of the Data
In this activity, the codeswitching forms are written in bold.

\section{Sebelum kita mulai} pelajaran saat ini, we are going to start with pray. Let's pray.

2. Yes ma'am. Our topic yesterday tentang global warming.

3. Mira, dapatkah anda jelaskan about global warming definition?

4. The effect of global warming is akan terjadi t'sunami ma'am.

5. Lina boleh pinjam your book?

6. Sementara saya membaca topik ini, please pay attention and listen to me.

7. Ok. Saya akan bacakan teks ini once again.

8. Jawabannya right. The temperature is high.

9. Ma'am we didn't understand about the exercise, tolong dijelaskan. 
10. Anda dipersilahkan untuk menjawab pilihan ganda according the text.

11. What you want to do untuk menghentikan global warming.

12. Can you participate for our friend Marsela Kuhu yang dirawat di rumah sakit.

13. No sir, just one number lagi.

14. Put your hand and sebutkan jawaban your group.

15. Ok. This is the last number. Silahkan baca number four.

16. Nia ternyata jawaban kita sama. The answer is wrong.

17. Ok everyone, our time is over. Kita lanjutkan with group five.

18. Mark kamari nda lama dang. Can I ask you something?

19. Have you finish your writing? Jika sudah selesai kami akan memberikan penjelasan.

20. Bagaimana denganmu Rivo? Do you have any plans?

21. Rani tunggu kita telepon for our planing next week.

22. Thank you very much, kita tunggu kabar darimu.

23. Have you ever visited a watefall or other natural tourist objects? Apa yang kamu sukai dan tidak kamu sukai ditempat tersebut?

24. Now you have to write your description dengan menambahkan kata, frase atau kalimat.

25. Ok guys, do you like ballet? Apa yang dimaksud dengan ballet?

26. The text is called a Memo. Ada yang tahu arti memo?

27. What do you think dengan guru Bahasa ingggris kita yang baru? 
She teachs us amazingly

karena itu Saya mulai

tertarik dengan Bahasa

inggris sekarang.

28. It's nice to go swimming,

Sheren apa kau tertarik

ikut dengan kami?

29. Kesya, what time will you be free? Kita punya proyek besar minggu ini.

30. Can you mention example tentang bagaimana laut bias terkontaminasi?

31. I want to know the reason kau tidak sekolah kemarin Dina.

32. Maria grew up in Mexico dan dia tidak punya keluarga disana.

33. So, why you don't wear your batik dress?

Bukanlah itu akan terlihat lebih bagus.

34. Kau benar Kasih, i will change my clothes.

35. I will take a bath selesai menyiram bunga.

36. Do you like eating junk food? Itu sangat lezat bukan?
37. What is in your mind ketika anda mendengar kata "Pinocchio"?

38. Thank God it rains. Kalimat ini menjelaskan the farmer expesses his reliefs karena sudah hujan.

39. Thanks God I got 10 for my mid test, ini kali pertama bagiku.

40. Can you explain some of language yang digunakan oleh beberapa orang dalam teks ini?

41. Teman-teman kita lihat halaman 23. Please open you book.

42. Ma'am di halaman 45 there is the language definition.

43. Randy can you help me? Pinjamkan saya pulpen?

44. Teman-teman kalian siap atau tidak, the new era is coming!

45. Based on the dialogue, Naira group tolong jawab pertanyaannya. 
46. Rival you answer the question di halaman 25 bagian $B$.

47. Excause me Ma'am. Saya ijin ke toilet sebentar.

48. I like reading very much, bagaimana denganmu Merry?

49. The impact of Global Warming terhadap keadaan bumi kita.

\section{Categorization of the Data}

The data presented in previous activity are categorized in the types of code switching, as what presented in the following:

\section{- Inter-Sentential}

In inter sentential code switching, the language switch is done at sentence boundaries. This is seen most often between fluent bilingual speaker, they are:

\section{Before we begin our lesson today, we are going to start with pray. Let's pray. \\ 2. Mira, can you explain about}

global warming definition?

3. While, i am reading this topic, please pay attention and listen to me.

4. You should answer the multiple choice according to the text.

\section{Can you} participate for our friend Marsela Kuhu who are in the Hospital.

6. Nia, Our answers are same. The answer is wrong.

7. Have you finish your writing? If you have finish, we are going to explain.

8. Thank you very much, I will wait your respons. 
9. Have you ever visited a waterfall

you know about

or other natural

memo?

tourist object?

What are you like

or dislike about

this place?

16. It's nice to go

swimming.

Sheren, do you

prefer to go with

us?

10. Kesya, what time

will you free? We

have a big projeck

this week.

11. Can you mention

the example of

how can the

ocean be

contaminated

12. Maria grew up in

Mexico but She

doesn't have any

family there.

13. I will take a bath

after wetting the

flower

14. Ok guys, do you

like ballet? What

do you mean of

ballet?

15. This teks is called

a Memo. Any of

17. I want to know the reason, why didn't you come to school yesterday, Dina

18. So, why don't you wear your batik dress? Doesn't it look beautiful?

19. Now, you have to write your description with add words, frases and sentenses

20. What do you think with our new english teacher?She teach us amazingly. So that, I begin to like about english now. 
21. Thanks God, I got

10 for my mid test, it is the first

time.

22. Can you explain some of language who used by some peoples from the teks.

23. The impact of global warming to the earth.

24. Ma'am, we didn't understand about the excercises, Please explain

25. ExcauseMaam, May I go to toilet?

26. I like reading very much, how about you Merry?

27. Do you like eating junk food? Isn't delicius?

28. What is in your mind when you listen about "Pinochio"?
29. Friends, let's see page twentythree. Please open your book.

30. Mam, in page

fourty-five there is the language definition

31. Randy can you help me? Borrow me a pen?

\section{- Intra sentential}

In intra sentential code switching, the language switch is done in the middle of a sentence with no interuptions, hesitations or pauses indicating a shift.

1. Yes Ma'am, Our Topic Yesterday was about global warming.

2. The effect of global warming is tsunami.

3. Ok. I will read this text once again

4. The answer is right. The 
temperature is

high.

5. What do you want to do to stop the global warming.

6. No Sir, just one number again.

7. Put your hand and tell me your group answer

8. Ok. This is the last number. Please read number four.

9. How about you Rivo? Do you have any plans?

10. Rani, I will call you for our planning nest week.

11. Thanks God it is rain. This sentence means the farmer express his relief because it has rain.

\section{- Tag switching}

Tag switching occurs when a tag from different language is inserted into an utterance in other language. Tag switching involves an exclamation a tag, or a parenthetical in other language.

1. Lina, may $i$ borrow your book?

2. Ok everyone, our time is up. We move to group five.

3. Mark, come here, please! Can I ask you something?

4. You right Kasih, I will change my clothes.

5. Friend, are you ready or not the new era is coming.

6. Based on the dialogue, Naira group answer the questions, please!

7. Rival, please answer the question part $B$ on page twenty-five.

JELLT (Journal of English Language and Literature Teaching) 


\section{Explanation of the Data}

1. "Sebelum kita mulai pelajaran saat ini, we are going to start with pray.

Let's pray."

("Before we begin our lesson today, we are going to start with pray. Let's pray".)

From the sentence above, the student wanted to ask his friends but he used Indonesian and then switched to English. The student wanted to his friend began the class activity with said thanks to God with praise the Lord. He wanted his friends prayed together.

2. "Mira, dapatkah anda jelaskan about global warming definition?" ("Mira, can you explain about global warming definition?")

In the sentence above, a teacher asked Mira to explain about the lesson.
The teacher used Indonesian and switch to English.

3. "sementara saya membaca topik ini, please pay attention and listen to me." ("While, $i$ am reading this topic, please pay attention and listen to me.")

The sentence above, teacher asked to his student to pay attention while he was reading the text. He wanted the student to understand about the lesson, he used Indonesian and switch English while he said the sentence to the students.

\section{4. “Anda dipersilahkan} untuk menjawab pilihan ganda according to the text."

("You should answer the multiple choice according to the text.") 
Based on the sentence, teacher used Indonesian and switch to English. Teacher wanted student $\mathrm{s}$ to answer the multiple choice, and they should answer the question according to the text.

5. "Can you participate for our friend Marsela Kuhu yang dirawat di rumah sakit"

("Can you participate for our friend Marsela Kuhu who are in the hospital') Belongs to sentence above, some of the student asked for participate to show the sympaty to their friends who were in the hospital. The student used English first and switched to Indonesian.

\section{6. “Nia, ternyata jawaban}

kita sama. The answer is wrong."
("Nia, our answers are

same. The answer is

wrong."

Based on the sentence above, Nia wanted to give her opinion to her friend about their work. Actually, they have answered the question and they recognized that they had same answers, that is wrong. From that sentence, we can see that Nia used Indonesian and then switched to English.

7. Have you finish your writing? Jika sudah selesai kami akan memberikan penjelasan.

("Have you finish your writing? If you have finish, we are going to explain.”)

From the sentences, we can know that a group discuss have gave their explanation, maybe, the other group don't understand about the 
topic, so they are going to

explained their material.

The member of group

began the sentence with

English and then switch to

Indonesian.

8. "Thank you very much, saya tunggu kabar darimu”

("Thank you very much, $\boldsymbol{I}$ will wait your respons")

From the sentence, a student said something to another student that he will wait the respon from a student. He used English and switch to Indonesian.

9. Have you ever visited a waterfall or other natural tourist object? Apa yang kamu sukai dan tidak sukai di tempat tersebut?"

("Have you ever visited a waterfall or other natural tourist object? What are you like or dislike about this place?
From the sentence, someone ask for the feeling of other perseon about tourist destination. He used English and then Indonesian

10. What do you think dengan guru Bahasa Inggris kita yang baru? She teachs us amazingly. Karena itu, saya mulai tertarik dengan Bahasa Inggris sekarang"

("What do you think with our new English teacher? She teachs us amazingly. So that, I begin to like about English now.")

The sentence above tell us about teacher asked his student about their new English teacher. And he answered that his new English teacher was amazing for that he began to like to study English. He used English first and then switch to Indonesian. 
11. Kesya, what time will you free? Kita punya proyek besar minggu ini." ("Kesya, what time will you free? We have a big project this week.")

From the text above, someone asked Kesya about her free time. She wanted Kesya to join with her because they have a big project to do. Kesya's friend used English then switched to Indonesian.

12. "Can you mention the example tentang bagaimana laut bias terkontaminasi” ("Can you mention the example of how can the ocean be contaminated") Sentence above tells us about the teacher asked his student about contaminated ocean. $\mathrm{He}$ wanted the student give the example of the topic disscusion, he used English and then switched to Indonesian.
13. Maria grew up in Mexico but dia tidak punya keluarga disana”. ("Maria grew up in Mexico but She doesn't have any family there.")

The sentence about student activity in class. The student was telling a story about someone. He told Maria life. He used English then switched Indonesian

14. "I will take a bath selesai menyiram bunga" ("I will take a bath after wetting the flower") The sentence above tell us about, someone's respons when they were going to meet up. He told his activity before they go together. He used English and then Indonesian.

15. Ok guys, do you like ballet? Apa yang dimaksud dengan ballet? ("'Ok guys, do you like ballet? What do you mean of ballet?") 
The sentence wanted to tell us about teacher wanted to dig the brainstorming of students about ballet, before the learn it. Teacher used English and then Indonesian.

16. This teks is called a

Memo. Ada yang tahu arti memo?"

("This teks is called a Memo. Any of you know about memo?")

The sentence above tell us about teacher activity in classroom. after he read the text, he wanted to know, do the student know the kind of the text that they have read. the teacher used English and then Indonesian.

17. "It's nice to go swimming. Sheren, apa kau tertarik ikut dengan kami?"

("It's nice to go swimming. Sheren, do you prefer to go with

us?")

From the sentence above, we knew that, someone wanted to know, if Sheren like to go for swimming with them. She used English and then switched to Indonesian.

18. I want to know the reason, kamu tidak sekolah kemarin, Dina ("I want to know the reason, why didn't you come to school yesterday, Dina")

From the sentence above, it showed that, teacher asked Dina why she didn't come to school yesterday, and teacher wanted Dina gave her reason why she didn't come to school. Teacher used English then switched to Indonesian.

19. So, why don't you wear your batik dress?

\section{Bukankah itu terlihat}

bagus? 
("So, why don't you wear your batik dress? Doesn't it look beautiful?")

From the sentence above, it showed that, someone gave her opinion about other style, he was going to make his friend believed with her dress. He used English and then Indonesian.

20. "Now, you have to write your description dengan menambahkan kata, frase atau kalimat".

("Now, you have to write your description with add words, frases and sentenses")

From the sentence above, teacher asked to his students to write a description about their lesson with add word, frase and sentences. The teacher used English and switched to Indonesian.
21. Thanks God, I got 10 for my mid test, ini pertama kali bagiku.

("Thanks God, I got 10 for my mid test, it is the first time.")

The sentence above show that, someone gave thanks to God for the first time he got Ten in Mid test. He wants to express his graceful for the first time he got it. He said it in English then switched to Indonesian.

22. Can you explain some of language yang

digunakan oleh beberapa orang dalam teks ini.

(“Can you explain some of language who used by some peoples in the teks.")

From the sentence we know that, teacher asked his student to explained the lesson, he wanted the student to explain the language that they find in 
text, that they have read.

teacher used English then

switched to Indonesian.

23. The impact of global

warming terhadap

keadaan bumi kita.

("The impact of global

warming to the earth.")

The sentence above

showed that student

wanted to explained about

the lesson about global

warming. Student used

English then switched to

Indonesian.

24. Ma'am, we didn't

understand about the

exercises, tolong

dijelaskan.

("Ma'am, we didn't

understand about the

exercises, Please

explain”)

The sentence above

showed that student

wanted to more

explanation about the

lesson to their teacher.

They didn't understand

the exercises so they asked their teacher to explained

the exercises more.

Student used English then switched to Indonesian.

25. Excause Maam, saya ïin

ke Toilet sebentar?

("Excause Maam, May I

go to toilet?")

From the sentence we

know that a student

wanted to go to toilet, and he ask to teacher to give

him permission to go

there. So, he used English

then switch to Indonesian.

26. I like reading very much,

bagaimana denganmu,

Merry?

("I like reading very

much, how about you

Merry?")

From the sentence above, Merry's friend ask her friend hobby. She asked Merry but she tells her like first. She asked Merry with English then switch to Indonesian. 
27. "Do you like eating junk food? Itu sangat lezat

bukan?"

("Do you like eating junk

food? Isn't very

delicius?")

Sentence above showed

that, a student asked

someone opinion about

food, especially junk food.

$\mathrm{He}$ asked his friend

opinion about that. $\mathrm{He}$

asked with English then

switch to Indonesian.

28. What is in your mind

\section{ketika anda mendengar}

kata "Pinochio"?

("What is in your mind

when you listen about

“Pinochio"?”)

Sentence above showed

that teacher technic while

teaching. To open the

class, he asked student with sentence like this. $\mathrm{He}$ wanted to know the student if they know the topic that they are going to study. When teacher says it, he used English and then switched to

Indonesian.

29. Friends, mari kita lihat

halaman 23. Please open your book.

("Friends, let's see page

twenty-three. Please open

your book.")

In the sentence above, student asked all his friend to open their book and look at page 23. He asked his friend used English and switched to Indonesian.

30. Mam, in page forty - five there is the language definition

("Mam, di halaman 45 there is the language definition")

The sentence showed us about student showed to their teacher about their lesson. The student showed the definition of something in book, and he told in used Indonesian then switched to English. 
31. Randy can you help me?

\section{Pinjamkan saya pulpen.”}

("Randy can you help

me? Borrow me a pen?")

The sentence showed the

conversation of two

students, someone asked

his friend to borrowed him

a pen, he asked if he can

got a pen from his friend.

$\mathrm{He}$ used English and

switched to Indonesian.

32. Yes Ma'am, Our Topic

Yesterday was tentang

global warming.

("Yes Ma'am, Our Topic

Yesterday was about global

warming.")

The sentence above told

about student's answer

about their lesson on

yesterday. $\mathrm{He}$ will

explainned the topic and

the answer he inserted

Indonesian in that

sentence. about means

something that show to

thing that have learn.

33. The effect of global

warming is tsunami.
("The effect of global

warming is tsunami.")

the sentence above show

the something happened

in ocean. It can be

dangerous to the people. It

can make many things

broken. And for this

sentence, is switch from

English to Indonesian.

34. Ok. Saya akan bacakan

teks ini once again

("Ok. I will read this teks

once again")

From the text we know

that student wanted to do something while they are learning. She wanted to read again the topic in order, her friend understand the lesson. She switched English to Indonesian.

35. Jawabannya right. The temperature is high.

("The answer is right.

The temperature is

high.”)

From the sentence we know, teacher wanted to 
respons the student

answered with say the

answer is right. He wanted

to make the student have

good feeling with his

answer. The teacher used

English then switched to

Indonesian.

36. What do you want to do

untuk menghentikan the

global warming.

("What do you want to do

to stop the global

warming.")

The sentence showed us

the teacher ask to student what will they do to end the something to happen especially global warming. What will they do, The teacher inserted Indonesian in English sentence that he used.

37. No Sir, just one number

lagi.

("No Sir, just one number again")

That sentence, teacher want to know, the students work. He asked their work, if they have finish or no. He asked in English but he and with Indonesian word.

38. Put your hand and sebutkan your group answer ("Put your hand and tell me your group answer") From the sentence, teacher ask the group discussion to answer their work. He wanted to group tell and explain their answer to the disscusion session. He said it while insert Indonesian word in English sentence.

39. Ok. This is the last number. Silakan baca number four.

("Ok. This is the last number. Please read number four.”) The sentence showed the teacher is checking the students' answer. And it is the last number. $\mathrm{He}$ wanted to check if it true or false. $\mathrm{He}$ inserted 
Indonesian words in

English sentence.

\section{Bagaimana denganmu}

Rivo? Do you have any

plans?

('How about you Rivo?

Do you have any plans?")

From the sentence, we can

see the question was given

by Rivo's friend to him.

He wanted to know if

Rivo had any plans to do.

While he was asking he

began with Indonesian

and finished with English.

41. Rani, tunggu kita telepon

for our planning next

week.

("Rani, I will call you for our planning next week.")

The sentence said that, someone told to Rani what shall she do to confirm their planning next week. She told that, she will tell Rani to make Rani know, what shall they do. She inserted Indonesian words in English sentences.
42. Thanks God it is rain. Kalimat ini menjelaskan the farmer express his relief karena sudah hujan.

("Thanks God it is rain.

This sentence means the farmer express his relief because it has rain.")

This sentence means, the praise of someone when it has rain. He wanted to express how grate the God for help them. While he said the sentences, he switched English to Indonesian, and English to Indonesian again.

43. Lina, boleh pinjam your book?

('Lina, may i borrow your book?")

The sentence above show the expresion of someone to Lina, when she is going to borrow Lina's book. He Swith Indonesian to English word when he asked it to Lina. 
44. Ok everyone, our time is up. Kita lanjutkan to group five.

("Ok everyone, our time is up, we move to group five.")

The sentence told us a teacher want to continues the lesson to the next group. He used Indonesian word to complete the sentence that she has used.

45. Mark, kamari nda lama

dang! Can I ask you

something?

("Mark, come here, please! Can I ask you something?")

It sentences show the expression of a student to ask permission to his friend. He wanted his friend come to him and he will ask something. He used Indonesian and switched to English.

46. Kamu benar Kasih, I will change my clothes. ("You right Kasih, I will change my clothes.”)
This sentence told us about someone expression while he agreed with other opinion. He wanted to do what have her friend said to her. She used Indonesian words then changed to Indonesian.

47. Friend, kalian siap atau

tidak the new era is coming.

("Friend, you are ready

or not the new era is coming.")

The sentence showed the expression of someone to make his friend agreed to the new era. He wanted his friend be ready what happen is done, because they should have to face it. $\mathrm{He}$ inserted Indonesian words in English sentence.

48. Based on the dialogue, Naira group tolong jawab pertanyaannya!

("Based on the dialogue, Naira group answer the questions, please!") 
The sentence told us expression they show by teacher to ask Naira group to do their responsibility to answer the excercises. He used English and then switched to Indonesian

49. Rival, please answer the question di halaman 25

\section{bagian $B$.}

("Rival, please answer the question part B on page twenty-five.")

From the sentence, teacher ask Rival to do their excercises, he gave the clue what should they do. Teacher used English and switched to Indonesian.

Their frequently use in firstly the code switching in the form of word there are 31 sentences of Intersentential, 11 sentences of Intra Sentential and 7 sentences of Tag Switching

\section{CONCLUSION}

After having discussed the code switching in English class, the writer came to the conclusion that, most of the code switching process are in the form of Inter sentential, Intra sentential and then Tag Switching. The description of the meaning depends of the context of the sentence.

\section{BIBLIOGRAPHY}

Bogdan, C.R. \&Biglen. 1992. Qualitative Research for Education : An Introduction to Theory and methods. Massachusetts.

Breadsmore, H.B. 1982. Bilingualism : Basic Principle. Clevedon : Tieto

Brown, H.D. 1994. Principle of Language Learning and Teaching.Engkwood Cliffs, N.J:Prentice Hall.

Burns, R. 2005. Introduction to Research Method. Thousand Oaks, CA: Sage.

Gumperz, J. 1977.Sociocultural Knowledge in Conversational Inference. In: M. SavilleTroike (ed.), 28th Annual Round Table Monograph Series on Languages and Linguistics. Washington, DC: Georgetown University Press

Leung, C. (2010). European journal of social sciences.

Code-mixing in Print Advertisement and its Cultural Implications in Hong Kong, 12, 417-429 
Muysken, P. (2000). Bilingual speech: A typology of codemixing.United Kingdom: Cambridge University Press

Nababan, P. W. J. 1986.

Sociolinguistics : Suatu

Pengantar. Jakarta.

Nunan, David. 1992. Research Methods in Language Learning. Cambridge University Press

Siahaan, Sanggan. 2008. Issues in Linguistics. Bogor. Ghalia Indonesia

Siregar, Bahren Umar. 1996. Code Alternation in Bilingual Speech Behavior. Medan :

Universitas Sumatera Utara Suwito. (1985). Sosiolinguistik : Pengantar Awal . Surakarta: Henary Offset

Wardhough, Ronald. 2002. An Introduction to Sociolinguistics, 4th en.Great Britain, Blackwell Publishers. 